\title{
Potential of local food use in the Ohio health care industry: An exploratory study
}

\author{
Brian Raison ${ }^{a *}$ \\ Ohio State University Extension, Miami County \\ Scott D. Scheer b \\ The Ohio State University
}

Submitted February 2, 2015/ Revised March 21 and April 9, 2015 / Accepted April 13, 2015 /

Published online June 11, 2015

Citation: Raison, B., \& Scheer, S. D. (2015). Potential of local food use in the Ohio health care industry:

An exploratory study. Journal of Agriculture, Food Systems, and Community Development, 5(3), 131-147.

http://dx.doi.org/10.5304/jafscd.2015.053.011

Copyright (C) 2015 by New Leaf Associates, Inc.

\begin{abstract}
Institutionalized foodservice in health care is evolving. Some hospitals have introduced local foods as a means of improving health and wellness. Investigation into the hospital foodservice literature, however, leaves unclear what percentage of hospitals actually participate in procuring, serving, or promoting local foods to patients and employees.

We investigated the factors that contributed to hospitals purchasing or not purchasing local foods for their operations. A census of Ohio hospital

\footnotetext{
a* Corresponding author: Brian Raison, Ph.D., Assistant Professor, Ohio State University Extension, Miami County; 201 West Main Street; Troy, Ohio 45373 USA; +1-937-4403948; raison.1@osu.edu

b Scott D. Scheer, Ph.D., Professor, Agricultural Communication, Education, and Leadership, The Ohio State University; 2120 Fyffe Road, Room 204C; Columbus, Ohio 43210 USA; +1-614-292-6758; scheer.9@,osu.edu
}

foodservice directors $(n=155)$ was undertaken in the fall of 2014. The response rate was $67.8 \%$. The broad research questions asked about how much knowledge they had of the local food movement, to what extent they currently used local foods (or had interest in purchasing local foods in the future) for their institutions, and what systemic issues advanced or impeded their institutional use of local foods.

We found that $77.9 \%$ of the respondents had knowledge of the local food movement. However, only $57.7 \%$ were currently using local foods in their operations. Even fewer were implementing programs related to local food. The findings revealed the major reasons for not incorporating local foods into operations were based on concerns over inconsistent supply levels, liability insurance, refrigeration, and other food safety issues. Lastly, the findings showed that foodservice directors are interested in programs that incorporate more local foods into their operations. 
These findings provide insight into how food systems workers can help hospitals, local farmers, and food production and/or distribution operations coalesce in triple-bottom-line results that deliver positive social, environmental, and economic outcomes.

\section{Keywords}

local food systems; health care; hospital foodservice; institutional foodservice

\section{Introduction: Local Foods in Institutions}

Local food has been described as items grown within a specific geographic area or within a specific distance from the point of consumer purchase (Buck, 2012). George (2011) and Martinez et al. (2010) note that definitions and attributes of local food vary greatly, but growers tend to perceive local as 20 to 50 miles (32 to 80 kilometers) from their farm. Over the past 10 years, the local food movement has significantly expanded across the country Johnson, Aussenberg, \& Cowan, 2013; Martinez et al., 2010; National Sustainable Agriculture Coalition, 2013; Sanger \& Zenz, 2004; Worley \& Strobbe, 2012). This was in response, in part, to the disconnection of people from the "sources of their sustenance" (Feenstra, 2002, p. 99). Along with the culmination of decades-old grassroots efforts, new U.S. Department of Agriculture (USDA) programs, such as "Farm to School" and "Know Your Farmer, Know Your Food," and Center for Disease Control and Prevention (CDC) healthy-food programs have intensified and bolstered efforts (CDC, 1996, 2013; Johnson et al., 2013; Ritchie \& Chen, 2011; USDA, 2013). Academic institutions have given support as well by procuring and serving local foods (Gustafson, 2012; Katzman \& Graham, 2011; Ritchie \& Chen, 2011; Sanger \& Zenz, 2004), and by developing beginning farmer programs at numerous universities, including Iowa State (Iowa State University, n.d.), Missouri, South Carolina, Nebraska, Ohio State, and others. The national land-grant university system's Extension service now offers a myriad of research, programming, and partnerships around local food systems in individual counties nationwide (eXtension, 2013). New farms with nontraditional proprietors are emerging to sell in local markets (Inwood \& Sharp, 2012; Low \& Vogel, 2011; Sharp, Clark, Davis, Smith, \& McCutcheon, 2011), and entrepreneurial gardens are flourishing (Feenstra, McGrew \& Campbell, 1999). In Ohio, the number of farmers markets has doubled since 2008 (Sylvester, 2011; USDA, 2012). A brief scan of the Internet will return numerous academic journals and posts from the popular press brimming with new research reports and feature stories on local food.

In the midst of this conversation, a generic construct of "farm to institution" has emerged (Ritchie \& Chen, 2011; USDA, 2013). The phrase is applied to schools, hospitals, businesses, nonprofits, and other large institutional purchasers (Sachs, 2011). In theory, if institutional purchasers engage in increased local foods procurement, more money will circulate in the local economy (Beery \& Vallianatos, 2004; Feenstra, 1997; Health Care Without Harm, 2006), and consumers will enjoy fresher foods picked at the height of ripeness, which may result in higher nutritional values (Center for Health and the Global Environment, 2012; Frith, 2007; Halweil, 2007; Matheson, 2012; Saha \& Nath, 2006).

By virtue of its implicit mission to improve the nation's health, the U.S. health care industry lies at the heart of this conversation. In its Healthy Hospital Choices report (Wiseman, Boothe, Reynolds, \& Belay, 2011), the CDC notes that hospitals, due to their large food procurement and purchasing power, have the potential to be powerful community leaders "by providing the healthiest food venues possible for their employees and community" (p. 4). They also call specifically for serving locally produced foods. This, in conjunction with the growing interest by federal agencies, nonprofits, and national foundations (e.g., Robert Wood Johnson Foundation, W. K. Kellogg Foundation, Winrock International), seems to indicate an increased potential to support "social solutions that address problems at the intersection of food, environment, and health" (Sachs, 2011, p. 100). These ideas can have a major impact on increasing local food use while at the same time promoting wellness among employees (Matheson, 2012), for example through interactions at hospital farmers markets or gardens. 
In 2009, the American Medical Association's Council on Science and Public Health prepared a report outlining the health effects of the predominant food industry system. This prompted the adoption of a California Medical Association resolution on sustainable food systems calling for "practices and policies to support 'healthy and ecologically sustainable food systems,' legislative advocacy at the federal level, and patient education efforts" (Sachs, 2011, p. 101). The Healthy Food in Health Care (HFHC) initiative emerged from Health Care Without Harm (HCWH) in 2005 to help hospitals improve their foodservices' sustainability. A key focus of the program included education, tools, and support for local and sustainably sourced food procurement, linking it to an institution's patients, staff, and community.

The sheer size of the nation's health care system places it in a position to participate in and affect this local food movement. But what issues, systemic to the health-care industry, advance or impede its participation?

The focus of this research project was on one segment of the health-care industry-hospitalsand their engagement with this highly visible local food movement. Sachs (2011) noted that sustainable food efforts had gained ground in the kindergarten-through-twelfth-grade and higher education sectors, but had not advanced as rapidly in health care. Hospitals have an inherent mission focused on health and wellness for not only patients but also their employees (Cromp, Cheadle, Solomon, Maring, Wong, \& Reed, 2012; Gaby, 2008; Matheson, 2012; Mitchell, 2009). So in theory they should be central in the conversation. The American Medical Association (2012) notes that a large predictor of both hospital patients' and the general public's health is the quantity and quality of food intake. Hence a hospital's stance on food (both communication about and delivery of) is of critical importance. Wellness and nutrition education and training programs and in-house foodservice should arguably be as important as medical treatment for overall patient and employee health (Cohen, 2013; Denton, n.d.).

The health-care foodservice industry is changing. This project aimed to discover if and how hospitals participate in one narrow segment of foodservice: local food procurement. As noted, the sheer number and size of hospitals (including patients and staff) provide great potential to impact market demand for local foods.

One important aspect that must be considered is healthy eating in hospital dining facilities. Across the country, the fast-food restaurants that once dominated hospital lobbies (Cram, Nallamothu, Fendrick \& Saint, 2002; Lesser, 2006; Lesser et al., 2012; Physicians Committee for Responsible Medicine, 2011) have been removed (Gordon, 2012; Lawrence, Boyle, Craypo \& Samuels, 2009). In some, establishments serving more healthy and local foods are taking their place. There have been some opponents of this change, who claim that comfort food may be therapeutic in some manner; however, the physical health implications outweighed these arguments.

Farmers markets have shown up on some hospital campuses as well. MacVean (2009) states that Kaiser Permanente was perhaps the first hospital system to utilize farmers markets to put nutrition within reachof employees, visitors, patients, and the community. In Ohio, the Cleveland Clinic has operated a local farmers market at its main campus for six years (Cleveland Clinic, 2013). It too aims to bring healthy, locally grown and produced foods to not only hospital employees and guests, but also to the local community.

Across the country, hospitals conduct employee wellness training and programming. These often cover exercise, diet, mental health (e.g., stress reduction), and other wellness issues. Most hospitals also conduct community outreach programming on health matters, and many provide volunteers and leadership to community improvement efforts. Could these all be tied together via local food systems thinking?

As documented by Louise Mitchell of the University of Maryland in her Local Foods to Local Hospitals report (2009), there are numerous anecdotal and popular-press accounts of hospitals that have begun to engage in the local food movement. She provided over 20 examples in her report's Appendix E (pp. 71-100). In addition, Kaiser Permanente (2013), The Nation (Klein, 2012), and numerous other articles and news reports have covered the phenomenon. However, these popular 
media articles and informally published reports are backed up by very few articles from scientific peerreviewed journals (Clancy, 2013; Ritchie \& Chen, 2011; Smith, Kaiser, \& Gómez, 2013). Of those that were available, most were very small and geographically concentrated. For example, the Fletcher Allen Health Care (now the University of Vermont Medical Center) in Burlington, Vermont (Bellows, Dufour, Bachmann, Green, \& Moore, 2013; Lee, 2013) has instituted programs to provide nutritious, local foods to patients and employees recognizing that "fresh food is vital to patients' health and aids in the healing process" (Bellows et al., 2013 , p. 9). But this was only one hospital. Worley \& Strobbe (2012) describe how a hospital in Iowa, Cass County Memorial, has been sourcing local food since 2005. It believes that "purchasing local produce promotes more vegetable intake" by both patients and employees (Worley \& Strobbe, 2012, p. 28). And on the east coast, the Maryland Hospitals for a Healthy Environment (MD H2E) launched a "Local Foods to Local Hospitals" project in September 2007 to encourage healthier local foods in hospitals and to support local farmers (Mitchell, 2009). This early initiative was one of the largest we discovered. It netted a measurable shift as nearly 20 hospitals began or increased their local food purchases. Again, with the limited academic literature on this topic, the data from this study may contribute valuable information for use in the field. Findings may point to opportunities for engaging hospital foodservice directors (FSDs) with interest in purchasing (or increasing the use of) local foods in their operations.

\section{Key Issues and Questions to Consider}

For the past 40 years, the nation's predominate food supply chain has been rooted in a highvolume, concentrated, and heavily conglomerated commodity process that has provided an abundant supply for U.S. citizens and much of the world (Lev \& Stevenson, 2013; Matson \& Thayer, 2013). In comparison to this system, the relatively recent and expansive growth in the local food movement may be described as a new or innovative approach in which we find early adopters, early majority, late majority, and laggards diffusing the idea in various stages of progression (Rogers, 1962, 1995).
As the local food movement spreads across the nation, one example of innovative diffusion in local food procurement can be found in the 10-year-old USDA Farm to School (F2S) program which is just now beginning to see broad success (Benson, 2013; Virginia Tech Department of Agricultural and Extension Education, 2012; National Farm to School Network, n.d.; Sanger \& Zenz, 2004; Ugalde, 2012). This success has likely been aided by stimulus programs, direct payments, and extensive publicity from the USDA. A recent study by the Virginia Cooperative Extension Service (Virginia Tech Department of Agricultural and Extension Education, 2012) provided examples of exactly how those programs were making an impact. Virginia's Page County Public School system, for example, sourced $37 \%$ of the produce it used in the 2012-2013 school year locally. A program participant said, "We hope this percentage will continue to grow so that children receive even more fresh, local produce" (p. 30).

Success in the school system begs one to investigate whether this innovation can penetrate other sectors or institutional systems. As noted, hospitals may constitute a natural fit for this inquiry due to their inherent mission and focus on health and wellness. However, aside from the aforementioned internal hospital newsletters and popular press accounts, investigation into the hospital foodservice literature leaves it unclear as to whether any sizable percentage of hospitals currently participate in procuring, serving, and/or promoting local foods to patients and employees. This may indicate a significant opportunity for hospital foodservice directors (FSDs) to engage with this movement. In doing so, they could positively affect the local economy via local food procurement (Low \& Vogel, 2011; O'Hara \& Pirog, 2013), stimulate hospital staff and patient awareness of and interest in healthy, nutritious eating via local foods, and achieve positive publicity in the community for their institution (Mitchell, 2009).

Incorporating local foods has become a relevant issue for hospitals with implications for social, environmental, economic, political, and public health systems. But what hinders hospital participation or adoption of this innovative 
movement? Are systemic issues advancing or impeding action? Will the innovation diffuse through hospital foodservice directors?

The purpose of this study was to understand, measure, catalogue, and evaluate what factors contributed to hospital FSDs purchasing or not purchasing local food for use in their operations. A census of Ohio hospital FSDs $(n=155)$ was undertaken. The following key themes guided our research:

- the level of knowledge Ohio hospital FSDs had of the local food movement and its relationship to health care;

- the extent to which FSDs currently used local foods, or their interest in purchasing local foods in the future;

- the issues that advanced or impeded FSDs use of local foods, and what challenges were seen as the greatest barriers; and

- the relationships between demographic variables and the use of local foods.

A fifth theme examined to what extent Ohio hospital FSDs were aware of the Cooperative Extension system and its programs on local foods. This thread will be explored in a separate manuscript focused explicitly on implications for Cooperative Extension.

\section{Methods}

The population frame consisted of all Ohio hospital FSDs. Ohio has numerous attributes that made it a good geographic frame for study. Since the 1980s Ohio has been utilized by national corporations as a test market for many new product trials (Knepper, 2003; Smith, 2012). It has a relatively dense, heterogeneous population that includes both rural expanses and urban centers. From a health-care perspective, Ohio has approximately 244 hospitals with 34,000 beds (Ohio Department of Health [ODH], n.d.). Each year, more than 1.5 million people are admitted to these facilities. In addition, outpatient visits total more than 30 million. Ohio also has approximately 275,000 employees who serve those patients each day (Ohio Hospital Association [OHA], 2014). These numbers suggest that there is a sizable potential for data gathering, analysis, and the subsequent informing of potential implications and/or programming. Therefore, though the results of this study are limited in their generalizability to other locations, this study may garner a broad interest outside the state for hospitals pursuing local foods, and for food system workers with interests in the topic.

The quantitative questionnaire was developed based on two existing instruments. One had been utilized by Benson (2013) during his study of Extension's participation in the USDA Farm to School (F2S) program that provides local food for use in school systems. The second was based on an instrument from Benson and Niewolny (Virginia Tech Department of Agricultural and Extension Education, 2012) used in their Virginia farm to school (F2S) survey. These research projects closely mirrored the inquiry of foodservice directors in this new Ohio hospital study. The issues of institutional food purchasing overlap substantially among schools, hospitals, or other large institutional buyers. The USDA (2013), in fact, uses the term "farm to institution" to convey the meaning of selling local foods to any institutional purchasers. The final instrument included three main sections and consisted of 22 numbered questions that included 36 total items.

An expert panel was used to review the instrument for validity. It was made up of 12 researchers and practitioners who were familiar with the local food movement and/or Extension's outreach in hospitals or institutions. The instrument was sent to these subject matter experts to judge its content validity. They also reviewed the instrument for face validity, a measure of how well respondents will understand the survey. The instrument was revised based on the panel's recommendations.

\section{Results}

The full quantitative survey instrument was administered to Ohio hospital FSDs in June 2014 via Lime Survey, a secure, online electronic survey website. A total of 155 potential Ohio hospital FSDs were contacted. A total of 105 responses were received for a $67.8 \%$ response rate. Cronbach's alpha coefficients were calculated for each construct in order to verify the indication of good 
reliability and internal consistency. The coefficients ranged from .714 to .912 .

This analysis reports summary findings using mostly nonparametric, descriptive statistics. The mean age of the responding 105 FSDs was 46; their average tenure on the job was 8.6 years; they oversaw between one and 13 hospital kitchens; they were $50.5 \%$ female; and nearly $94 \%$ were white. The hospitals in the study varied greatly in terms of staffing and meal production and output. Table 1 provides a summary of the foodservice characteristics of the hospitals.

Hospitals with contracted foodservice were asked about their foodservice vendor. Hospitals that do not use contracted foodservice were asked to list their three major suppliers. Results indicated a high concentration on a limited number of large, national broadline food distribution suppliers and group purchasing organizations (GPOs).

The following section present results from the four themes explored in the study:

\section{The level of knowledge Ohio hospital FSDs had of the local food movement and its relationship with health care.}

In this initial theme, we found that just over half, $54.9 \%$, of FSDs felt the use of local foods has been increasing among U.S. hospitals. However, only $45.6 \%$ indicated that they knew how to find and purchase local foods to serve in their hospital(s). Knowledge of government programs to

\section{Table 1. Hospital Characteristics}

\begin{tabular}{|c|c|c|}
\hline & Frequency $(n)$ & Percent (\%) \\
\hline \multicolumn{3}{|l|}{ Location $^{a}$} \\
\hline Rural & 57 & 46.3 \\
\hline Urban & 38 & 30.9 \\
\hline Suburban & 28 & 22.8 \\
\hline \multicolumn{3}{|l|}{ Foodservice } \\
\hline Contracted out & 37 & 35.2 \\
\hline In-house & 68 & 64.8 \\
\hline \multicolumn{3}{|l|}{ Type of cooking (percent) } \\
\hline Scratch cooked & $31 \%$ & \\
\hline Heat and serve cooked & $69 \%$ & \\
\hline \multicolumn{3}{|l|}{$\begin{array}{l}\text { Number of staff (as full-time } \\
\text { equivalents [FTEs]) }\end{array}$} \\
\hline Range & \multicolumn{2}{|l|}{3 to 800} \\
\hline Mean & \multicolumn{2}{|l|}{61.5} \\
\hline Mode & \multicolumn{2}{|c|}{$\begin{array}{l}\text { Multiple: } 6,9,10,25 \text {, } \\
\quad 35\end{array}$} \\
\hline \multicolumn{3}{|l|}{ Average number of meals/day } \\
\hline Patient & \multicolumn{2}{|c|}{$\begin{array}{c}490 \text { (Multiple modes: } \\
45,100,300)\end{array}$} \\
\hline $\begin{array}{l}\text { Staff and visitor (Monday- } \\
\text { Friday) }\end{array}$ & \multicolumn{2}{|c|}{$1,702($ Mode $=250)$} \\
\hline
\end{tabular}

a Responses total 123 as respondents could choose more than one answer.

help hospitals and the USDA's support of local food use in hospitals were the least known resources, with only $19.5 \%$ and $15.6 \%$, respectively, of FSDs reporting knowledge of them.

Overall, we found that $77.9 \%$ of the respondents were "hearing more about" the local food movement, but only $57.7 \%$ (Table 4) were

Table 2. Level of Knowledge of Local Foods

\begin{tabular}{|c|c|c|c|c|c|c|}
\hline Variable & $\begin{array}{c}\text { \# of } \\
\text { Responses }\end{array}$ & $\begin{array}{l}\text { Strongly } \\
\text { Disagree }\end{array}$ & Disagree & Neutral & Agree & $\begin{array}{l}\text { Strongly } \\
\text { Agree }\end{array}$ \\
\hline $\begin{array}{l}\text { I have been hearing more about local foods } \\
\text { (in general) in the past few years. }\end{array}$ & $n=104$ & $0.0 \%$ & $5.8 \%$ & $16.3 \%$ & $25.0 \%$ & $52.9 \%$ \\
\hline $\begin{array}{l}\text { The use of local foods has been increasing } \\
\text { among hospitals in the U.S. }\end{array}$ & $n=102$ & $2.0 \%$ & $9.8 \%$ & $33.3 \%$ & $29.4 \%$ & $25.5 \%$ \\
\hline $\begin{array}{l}\text { I know how to find local foods to serve in my } \\
\text { hospital. }\end{array}$ & $n=103$ & $7.8 \%$ & $18.4 \%$ & $28.2 \%$ & $26.2 \%$ & $19.4 \%$ \\
\hline $\begin{array}{l}\text { I know how to purchase local foods to serve } \\
\text { in my hospital. }\end{array}$ & $n=102$ & $7.8 \%$ & $21.6 \%$ & $25.5 \%$ & $22.5 \%$ & $22.5 \%$ \\
\hline $\begin{array}{l}\text { There are government programs to help } \\
\text { institutions learn how to buy local foods. }\end{array}$ & $n=103$ & $10.7 \%$ & $19.4 \%$ & $50.5 \%$ & $11.7 \%$ & $7.8 \%$ \\
\hline $\begin{array}{l}\text { The USDA “Know Your Farmer, Know Your } \\
\text { Food” program supports hospital } \\
\text { participation in local foods procurement. }\end{array}$ & $n=103$ & $8.7 \%$ & $18.4 \%$ & $57.3 \%$ & $10.7 \%$ & $4.9 \%$ \\
\hline
\end{tabular}

Note: Total possible $n=105$. 
participating in it. This was consistent with anecdotal evidence from hospital internal literature (newsletters, communications, websites) that provided numerous examples of local food connections and programs at hospitals across the U.S., but which often did not detail the extent or reach of the local food programming or use. Table 2 provides additional detail on specific aspects of FSDs' knowledge of local foods.

Respondents also provided information about their participation in activities associated with gaining more information on using local foods in hospitals. This specific construct measured actual past behavior in learning or communicating about local foods, thus providing an immediate and recent indication of their knowledge (by learning their interest and action). For this question, FSDs responded to statements indicating "yes" or "no." We also probed for an indication of future plans by including the option of checking, "I plan to in the next 12 months."

Here, we found that only $25.9 \%$ have not sought information on using local foods in their operations. The remaining items were split roughly $55 \%$ to $45 \%$, indicating that just over half have done some level of additional investigation on the issue. Table 3 provides additional detail of their potential interest and action around local food.

It may be noteworthy that over $70 \%$ indicated they had sought out information about using local foods or were planning to in the next 12 months. But only half had communicated with other hospitals about local foods, asked their broadline distributors to procure them, asked their administration to support local, and/or assisted with planting a hospital garden or establishing a farmers market at their hospital.

\section{The extent to which FSDs currently used local foods, or their interest in purchasing local foods in the future.}

This theme was designed to explore the current activity and behavioral intentions of hospital FSDs toward local food use. FSDs responded whether they were currently using local foods in their operations (see Table 4). For those who indicated "yes," a skip-logic program moved them to a questioning series that probed the extent of their local food use as well as a ranking of the factors most important to that activity.

\section{Table 4. Current Local Food Users $(n=104)$}

\begin{tabular}{lcc}
\hline Variable & Frequency $(n)$ & Percent (\%) \\
\hline Local food user: & & \\
No & 44 & 42.3 \\
Yes & 60 & 57.7 \\
\hline
\end{tabular}

Current local food using hospital FSDs provided data about their participation in activities such as farm to hospital, composting, community supported agriculture (CSAs), farmers markets, gardens, and wellness campaigns using local foods. Again, this question went only to the 60 respondents who indicated that they were currently using local food. Table 5 provides a summary of the
Table 3. Potential Interest and Action Around Local Food

\begin{tabular}{lccc}
\hline Variable & Yes (\%) & $\begin{array}{c}\text { I plan to within 12 } \\
\text { months (\%) }\end{array}$ & No (\%) \\
\hline $\begin{array}{l}\text { Have you ever sought out information about using } \\
\text { local foods in hospital cafeterias? }\end{array}$ & 55.6 & 14.8 & 25.9 \\
\hline $\begin{array}{l}\text { Have you ever communicated with other hospital food } \\
\text { service professionals about serving local foods? }\end{array}$ & 44.4 & 8.3 & 42.6 \\
$\begin{array}{l}\text { Have you ever asked your broadline distributor/GPO to } \\
\text { procure local foods? }\end{array}$ & 42.6 & 7.4 & 45.4 \\
$\begin{array}{l}\text { Have you ever asked your hospital administration to } \\
\text { support local food use? }\end{array}$ & 39.8 & 11.1 & 44.4 \\
\hline $\begin{array}{l}\text { Have you ever helped arrange a farmers market or } \\
\text { garden at your hospital? }\end{array}$ & 45.4 & 6.5 & 43.5 \\
\hline
\end{tabular}

Note: $n=105$ for each response. Totals do not equal $100 \%$ due to missing responses. responses regarding their interest and action around local food. Of note here is that just over $71 \%$ of respondents had conducted and/or planned healthy eating and/or wellness education using local foods at their operations. 
Table 5. Potential Interest and Action Around Local Food (current local food users)

\begin{tabular}{lcccc}
\hline Variable & Yes (\%) & $\begin{array}{c}\text { I plan to within } \\
\text { 12 months (\%) }\end{array}$ & No (\%) & Frequency $(n)^{\text {a }}$ \\
\hline Farm market at hospital & 34.4 & 6.9 & 58.6 & 58 \\
\hline CSA (community supported agriculture) program at hospital & 16.9 & 13.5 & 69.5 & 59 \\
\hline Gardens at hospital (employee or patient) & 22.8 & 12.3 & 64.9 & 57 \\
\hline Composting food waste & 22.0 & 15.3 & 62.7 & 59 \\
\hline Healthy eating and/or wellness education using local foods & 61.0 & 10.1 & 28.8 & 59 \\
\hline
\end{tabular}

a Totals do not equal $100 \%$ due to rounding.

But other programs are not being adopted as frequently.

Both FSDs who used local food and those who did not also responded to inquiries that measured their attitudes about potential benefits of and problems with using local foods. Table 6 provides detail on specific aspects of FSDs' attitudes. The top-ranked item showed FSDs felt that hospitals could support their local economy and help create jobs by using local foods, with $85.1 \%$ agreeing or strongly agreeing.

Table 7 provides detail on the responses of hospital FSDs' attitudes as measured by inquiring about potential problems of using local foods. Seasonal availability garnered the highest level of agreement or strong agreement. However, the remaining six items had between $32 \%$ and $45 \%$ "neutral" responses. These could be an indication of neither agreement nor disagreement; or they could indicate that FSDs were unsure or undecided. On the cost issue, $49 \%$ felt local foods cost too much; however, $40 \%$ checked "neutral." Data from other studies may provide clues. That is, some foods may be more expensive, but perhaps not all the time (depending on the seasonal availability). These questions would benefit from further inquiry. Language in foodservice contracts that limited purchasing of local foods, and the possibility that local foods have little or no support from hospital administration, were rated lowest in agreement.

\section{Non-Users of Local Food}

As noted, approximately $42 \%(n=44)$ of respondents were not currently using local foods in their hospital foodservice operation. These FSDs provided input (via a skip-logic sequence that moved them to a separate questioning series) that

Table 6. Attitudes as Measured by Inquiring About Potential Benefits

\begin{tabular}{|c|c|c|c|c|c|c|}
\hline Variable & $\begin{array}{c}\text { \# of } \\
\text { Responses }\end{array}$ & $\begin{array}{l}\text { Strongly } \\
\text { Disagree }\end{array}$ & Disagree & Neutral & Agree & $\begin{array}{c}\text { Strongly } \\
\text { Agree }\end{array}$ \\
\hline $\begin{array}{l}\text { Hospitals can support their local economy } \\
\text { and help create jobs. }\end{array}$ & $n=101$ & $2.0 \%$ & $1.0 \%$ & $11.9 \%$ & $36.6 \%$ & $48.5 \%$ \\
\hline $\begin{array}{l}\text { Patients and employees can have healthier } \\
\text { diets. }\end{array}$ & $n=101$ & $4.0 \%$ & $4.0 \%$ & $18.8 \%$ & $37.6 \%$ & $35.6 \%$ \\
\hline $\begin{array}{l}\text { The hospital's public relations are } \\
\text { enhanced. }\end{array}$ & $n=99$ & $1.0 \%$ & $4.0 \%$ & $23.2 \%$ & $40.4 \%$ & $31.3 \%$ \\
\hline $\begin{array}{l}\text { Rates of overweight and obesity can be } \\
\text { reduced via heightened interest in healthy } \\
\text { food. }\end{array}$ & $n=101$ & $4.0 \%$ & $8.9 \%$ & $19.8 \%$ & $32.7 \%$ & $34.7 \%$ \\
\hline $\begin{array}{l}\text { Hospitals know more about the source and } \\
\text { production of their foods. }\end{array}$ & $n=101$ & $2.0 \%$ & $11.9 \%$ & $21.8 \%$ & $40.6 \%$ & $23.8 \%$ \\
\hline $\begin{array}{l}\text { Patients and employees more likely to } \\
\text { choose healthy options when they know it's } \\
\text { local. }\end{array}$ & $n=100$ & $4.0 \%$ & $16.0 \%$ & $36.0 \%$ & $22.0 \%$ & $22.0 \%$ \\
\hline
\end{tabular}

Note: Total possible $n=105$. 
Table 7. Attitudes as Measured by Inquiring About Potential Problems

\begin{tabular}{|c|c|c|c|c|c|c|}
\hline Variable & $\begin{array}{c}\text { \# of } \\
\text { Responses }\end{array}$ & $\begin{array}{l}\text { Strongly } \\
\text { Disagree }\end{array}$ & Disagree & Neutral & Agree & Strongly Agree \\
\hline The seasonal availability issues. & $n=100$ & $3.0 \%$ & $11.0 \%$ & $23.0 \%$ & $35.0 \%$ & $28.0 \%$ \\
\hline Local foods cost too much. & $n=100$ & $3.0 \%$ & $8.0 \%$ & $40.0 \%$ & $37.0 \%$ & $12.0 \%$ \\
\hline There is an inadequate supply or volume. & $n=100$ & $5.0 \%$ & $11.0 \%$ & $38.0 \%$ & $32.0 \%$ & $14.0 \%$ \\
\hline $\begin{array}{l}\text { Delivery issues: timing; crate, pallet, or box } \\
\text { size. }\end{array}$ & $n=99$ & $8.1 \%$ & $14.1 \%$ & $39.4 \%$ & $24.2 \%$ & $14.1 \%$ \\
\hline Ordering procedures are complicated. & $n=98$ & $8.2 \%$ & $14.3 \%$ & $44.9 \%$ & $18.4 \%$ & $14.3 \%$ \\
\hline $\begin{array}{l}\text { Local foods have little or no support from } \\
\text { hospital administration. }\end{array}$ & $n=99$ & $19.2 \%$ & $20.2 \%$ & $37.4 \%$ & $18.2 \%$ & $5.1 \%$ \\
\hline $\begin{array}{l}\text { Language in my foodservice contract limits } \\
\text { purchasing of local foods. }\end{array}$ & $n=99$ & $24.2 \%$ & $21.2 \%$ & $32.3 \%$ & $13.1 \%$ & $9.1 \%$ \\
\hline
\end{tabular}

Note: Total possible $n=105$.

explained the extent of their potential interest in local food use as well as a ranking of the factors that would be most important to adopting the practice of using local food. They also provided information as to what might increase their likelihood to purchase local foods.

The non-users of local food ranked quality as the most important factor, with price, delivery, availability, and liability insurance all receiving rankings at or near "very important" as well. The attributes of preprocessing and/or organic did not rate as important. Details are in Table 8.

Current non-users also provided information on what might increase their likeliness to purchase local foods. Table 9 shows that $75 \%$ of FSDs indicated agreement that they would be more likely to purchase and serve local foods if their broadline food distributor offered more local items, and they would buy more if they had a guidebook on how to source and purchase local foods. Only 17\% agreed that having different food preparation facilities and/or equipment would increase their likelihood of using local foods; however, $41.5 \%$ of those marked "neutral," which could mean they are unsure about those implications. That said, 41.4\% disagreed, perhaps indicating that facilities are not an issue.

\section{The issues that advanced or impeded FSDs' use of local foods, and what challenges were seen as the greatest barriers.}

FSDs who currently used local foods $(n=60)$ said they considered quality to be the most important item, with $100 \%$ giving it a " 4 " or " 5 " ranking. This was followed closely by availability and

Table 8. Factors Non-users Rank as Most Important When Considering Local Foods

\begin{tabular}{lcccccc}
\hline Variable & $\begin{array}{c}\text { \# of } \\
\text { Responses }\end{array}$ & $\begin{array}{c}\mathbf{1}=\text { Not } \\
\text { Important }\end{array}$ & $\mathbf{2}$ & $\mathbf{3 = \text { Neutral }}$ & $\begin{array}{c}\mathbf{4}=\text { Very } \\
\text { Important }\end{array}$ \\
\hline Quality & $n=42$ & $0.0 \%$ & $0.0 \%$ & $4.8 \%$ & $11.9 \%$ & $83.3 \%$ \\
\hline Price & $n=42$ & $0.0 \%$ & $0.0 \%$ & $7.1 \%$ & $26.2 \%$ & $66.7 \%$ \\
\hline Availability & $n=42$ & $0.0 \%$ & $0.0 \%$ & $9.5 \%$ & $28.6 \%$ & $61.9 \%$ \\
\hline Delivery & $n=42$ & $0.0 \%$ & $0.0 \%$ & $11.9 \%$ & $21.4 \%$ & $66.7 \%$ \\
\hline Grower/producer liability insurance & $n=42$ & $0.0 \%$ & $0.0 \%$ & $16.7 \%$ & $14.3 \%$ & $69.0 \%$ \\
\hline Quantity and/or volume & $n=41$ & $0.0 \%$ & $0.0 \%$ & $22.0 \%$ & $31.7 \%$ & $46.3 \%$ \\
\hline $\begin{array}{l}\text { Attributes such as organic, natural, or } \\
\text { antibiotic-free }\end{array}$ & $n=42$ & $4.8 \%$ & $19.0 \%$ & $28.6 \%$ & $28.6 \%$ & $19.0 \%$ \\
\hline $\begin{array}{l}\text { Preprocessing: chopped (size) or portion } \\
\text { (weight) }\end{array}$ & $n=42$ & $16.7 \%$ & $7.1 \%$ & $35.7 \%$ & $23.8 \%$ & $16.7 \%$ \\
\hline
\end{tabular}

Note: Total possible $n=44$. 
Table 9. Likeliness Factors Non-users Rank as Most Important When Considering Buying Local Foods

\begin{tabular}{|c|c|c|c|c|c|c|}
\hline $\begin{array}{l}\text { Variable } \\
\text { I would be more likely to purchase and } \\
\text { use local foods if... }\end{array}$ & $\begin{array}{c}\text { \# of } \\
\text { Responses }\end{array}$ & $\begin{array}{l}\text { Strongly } \\
\text { Disagree }\end{array}$ & Disagree & Neutral & Agree & $\begin{array}{l}\text { Strongly } \\
\text { Agree }\end{array}$ \\
\hline $\begin{array}{l}\text {...my broadline/GPO offered more local } \\
\text { foods. }\end{array}$ & $n=40$ & $0.0 \%$ & $7.5 \%$ & $17.5 \%$ & $37.5 \%$ & $37.5 \%$ \\
\hline $\begin{array}{l}\text {... had a guidebook on how to source and } \\
\text { purchase local foods. }\end{array}$ & $n=40$ & $0.0 \%$ & $10.0 \%$ & $15.0 \%$ & $37.5 \%$ & $37.5 \%$ \\
\hline $\begin{array}{l}\text {... had better food safety information about } \\
\text { local foods. }\end{array}$ & $n=41$ & $0.0 \%$ & $12.2 \%$ & $22.0 \%$ & $31.7 \%$ & $34.1 \%$ \\
\hline $\begin{array}{l}\text {...I had more info about purchasing } \\
\text { experience of other hospitals. }\end{array}$ & $n=41$ & $0.0 \%$ & $17.1 \%$ & $24.4 \%$ & $26.8 \%$ & $31.7 \%$ \\
\hline $\begin{array}{l}\text {...there were more interest from } \\
\text { administration. }\end{array}$ & $n=42$ & $2.4 \%$ & $11.9 \%$ & $28.6 \%$ & $26.2 \%$ & $31.0 \%$ \\
\hline ...there were more interest from employees. & $n=41$ & $4.9 \%$ & $14.6 \%$ & $24.4 \%$ & $36.6 \%$ & $19.5 \%$ \\
\hline ...there were more interest from patients. & $n=41$ & $7.3 \%$ & $22.0 \%$ & $19.5 \%$ & $26.8 \%$ & $24.4 \%$ \\
\hline $\begin{array}{l}\text {... had additional or different food } \\
\text { preparation facilities. }\end{array}$ & $n=41$ & $14.6 \%$ & $26.8 \%$ & $41.5 \%$ & $7.3 \%$ & $9.8 \%$ \\
\hline
\end{tabular}

Note: Total possible $n=44$.

delivery. Table 10

provides additional

details. As with the non-local food using FSDs, attributes such as organic or preprocessing did not rank as highly, but "quality" was ranked as most important by non-users as well.

Hospital FSDs who currently used local foods were also asked in an open-ended question about challenges they had encountered with buying local foods. A total of 58 persons responded with 31 (53.4\%) saying "yes," they had had issues. Challenges included:

- Obtaining the quality that customers expect;

- Obtaining the quantity we need at the time we need the product;

- Space for a garden or composting;

- Grower/producer liability insurance;

- Concern with food safety;
Table 10. Factors Current Users Find Most Important to Consider When Buying

\begin{tabular}{lccccc}
\hline Variable & $\begin{array}{c}\mathbf{1}=\text { Not } \\
\text { Important }\end{array}$ & $\mathbf{2}$ & $\mathbf{3}=$ Neutral & $\mathbf{4}$ & $\begin{array}{c}5=\text { Very } \\
\text { Important }\end{array}$ \\
\hline Quality & $0.0 \%$ & $0.0 \%$ & $0.0 \%$ & $18.6 \%$ & $81.4 \%$ \\
\hline Availability & $0.0 \%$ & $0.0 \%$ & $6.8 \%$ & $39.0 \%$ & $54.2 \%$ \\
\hline Delivery & $0.0 \%$ & $1.7 \%$ & $8.5 \%$ & $35.6 \%$ & $54.2 \%$ \\
\hline $\begin{array}{l}\text { Grower/producer liability } \\
\text { insurance }\end{array}$ & $3.4 \%$ & $1.7 \%$ & $8.5 \%$ & $18.6 \%$ & $67.8 \%$ \\
\hline Price & $0.0 \%$ & $1.7 \%$ & $13.6 \%$ & $37.3 \%$ & $47.5 \%$ \\
\hline $\begin{array}{l}\text { Quantity and/or volume } \\
\text { Attributes such as organic, } \\
\text { natural, or antibiotic-free }\end{array}$ & $0.0 \%$ & $1.7 \%$ & $13.6 \%$ & $30.5 \%$ & $54.2 \%$ \\
\hline $\begin{array}{l}\text { Preprocessing: chopped } \\
\text { (size) or portion (weight) }\end{array}$ & $8.1 \%$ & $10.2 \%$ & $35.6 \%$ & $22.0 \%$ & $27.1 \%$ \\
\hline
\end{tabular}

- Delivery and shipment sizes; and

- Locked into contract with a broadline supplier.

For example, concerning the liability issue, one respondent wrote that, "To take advantage of truly local and/or small farms means potential liability re: sanitation. Have tried to keep majority of produce w/ my local produce company as a compromise." Another added, "Our health inspector recommended no farmers market food 
unless proof of insurance was obtainable."

On the other hand, liability insurance, quality, and other attributes may not be the only issues with purchasing locally grown foods. One respondent said that buying local is not always clear. He or she provided a counterexample, noting:

"There is a large grey area that isn't being considered when buying local. For example, should I purchase Ohio tomatoes that need constant irrigation and fertilization to keep growing, and end up getting a final yield of $1000 \# /$ acre at $\$ 25 /$ case because they mainly sell to retail markets first. Or should I buy California tomatoes, where the farm is collecting rain water, and recycling irrigation, turning their greenhouse gas emissions into fuel for the harvesting/processing and the final yield is $2500 \# /$ acre which I can get for $\$ 15 /$ case, as they are specifically grown for food service?"

Another respondent was hopeful that this hospital FSD survey might provide a means to increase his or her purchases, saying:

"There are a number of challenges to buying local. Traceability and liability insurance, the amount of the items available, price of the items.... We are committed to buying local, and increasing the amount of items used, hopefully this process will help us drive those amounts."

Another respondent mentioned the proliferation of field corn and soybeans, but the lack of crop diversity, noting that "[There is] not a good source of fruits and vegetables. I can get apples in the fall and we feature those. We need more growers and coop organization so we have better access to the volume we need."

It is noteworthy that some of the concerns expressed in these findings have been addressed already by a few hospital operations in other parts of the country. For example, the Healthy Food in Health Care program provides guidance and expertise to help hospitals develop more sustainable food purchasing systems, including local foods
(HCWH, 2013). Other initiatives, including the Healthier Hospitals Initiative (HHI), Balanced Menus, Local \& Sustainable Purchasing, and Healthy Beverages (Bellows et al., 2013) are also working to remove barriers to participation. More recently, broadline distributors or GPOs (group purchasing organizations) that procure, aggregate, warehouse, and often process foods for hospitals (Sanger \& Zenz, 2004; Stevenson \& Pirog, n.d.) are beginning to offer hospitals some local food options.

In addition, some hospital administrations have begun to increase local food purchasing by writing policies into their food service department's plans (Worley \& Strobbe, 2012). Lee (2013) notes that when Hospital Sisters Health System (a 13hospital system based in Springfield, Illinois) renewed its broadline contract in 2011, it specified that a quarter of the system's food must come from local sources.

Again, the major reasons identified in this study for not incorporating any (or additional) local foods into operations were based on supply availability (lacking significant quantity that could be delivered when needed), and potential safety concerns (lacking liability insurance, washing, refrigerated delivery). But overall, findings suggest that many of these barriers may be quite surmountable in Ohio as they have been in other parts of the nation.

\section{The relationships between demographic variables and the use of local foods.}

The Ohio hospital FSDs provided information on their personal characteristics and hospital demographics. We used statistical tests based on the number and type of variables to determine potential relationships or associations with the use of local food. Overall, the data analysis indicated that demographic variables did not appear to have any significant impact on local food use. The demographic variables most related to local food use were hospital size (number of full-time-equivalent staff) and average patient meals (number served per day). Hospitals with more employees and serving more patient meals were slightly more likely to use local foods. There were very slight indications that suburban and urban hospitals may 
be more likely to use local foods, and that younger (age) and less tenured (number of years in the profession) FSDs may be slightly more inclined toward local food use as well. There were no indications of variation by sex. No conclusions could be drawn on race because nearly all respondents were white. Studies in the literature and stories from industry newsletters did not provide any insight or data on these demographic characteristics (relating to local food use) either.

\section{Conclusions}

The purpose of this study was to understand, measure, catalogue, and evaluate what factors contributed to hospital foodservice directors (FSDs) purchasing or not purchasing local food for use in their operations. Overall, Ohio hospital FSDs expressed a definite interest in adopting or increasing the use of local foods in their operations; however, as noted above, there are several areas of concern that need to be addressed before widescale increases will be seen. Additionally, the topics with high levels of "neutral" responses may benefit from further investigation, particularly in the form of personal interviews to better understand what was meant. Overall, the data clearly indicate that there are opportunities for food systems workers to engage in local food programming with hospitals, and perhaps within the industrial sector that includes other health-care operations as well.

The Institute of Food Technologists (IFT), a 75-year old organization that serves the food science community, recently published a summary of trends and innovation around healthy hospital initiatives that posited similar findings as this study (IFT, 2012), although it lacked attitudinal and interest measures. In brief, the IFT study found that hospitals have the opportunity to increase offerings of fresh fruits and vegetables, increase restaurantstyle, cooked-to-order items for patients and cafeteria visitors, and offer pricing strategies to incentivize healthier selections. They also state that hospitals can serve as role models in worksite wellness, noting that the more than 5,750 hospitals registered in the United States see nearly 37 million patients and employ over 5 million workers. Local foods programming may be an entry point for many of these wellness strategies. This study confirmed that the interest was there.

The results from this study may be immediately helpful in launching some of the future research or programming efforts outlined above. If the results are shared with hospital wellness coordinators, nutrition educators, and administrators, they could prompt further use of local foods in hospital operations. It is hoped that these efforts might also lead to long-term partnerships that increase the number of connections between hospitals and farmers, ultimately leading to increased local food production and consumption, which would increase the number of jobs in agriculture. These connections can help reduce questions about local food safety (e.g., by providing education regarding good agricultural practice [GAP] initiatives that improve food safety handling practices).

New outreach, partnerships, and farm-tohospital (FTH) programming could be conceived and implemented around findings from this project. Food system workers, researchers, and educators within the Extension departments of landgrant universities may use these findings as a baseline upon which to begin new or expand existing (e.g., GAP) programming in the local food system arena. Dunning et al. (2012) suggested this as well, pointing to the potential for tapping Extension's structural and relationship networks to encourage change in institutional food systems. Specifically, these findings provide insight into areas in which one might approach a hospital or health-care operation-essentially identifying intersections at which connections and new programming can begin.

This project addressed a relatively narrow slice of the topic of using local foods within the healthcare (specifically, Ohio hospitals) industry. Additional research is needed to determine if the idea of using local food offerings might be able to have further-reaching implications. Some potential questions for future investigation could ask if local foods might:

- Stimulate interest and sales in hospital cafeterias;

- Increase interest and participation in employee wellness programs (through local foods education, farm tours, CSA memberships, or on-site farmers markets); 
- Provide a hot topic for hospitals to develop programming and training on where, how, and why employees should access healthy, local foods;

- Educate employees on the potential positive economic impact that may be achieved through local foods shopping; and/or

- Increase healthier food consumption at both work and home.

The answers to these questions could additionally inform food system workers across the state and nation, providing insight into the hows and whys of farm to hospital purchasing, thus allowing them to develop new approaches to inform or encourage the process and increase local food use by hospitals and health-care organizations. Again, this could lead to positive contributions to local economies, public health, and the community as a whole.

As noted previously, Smith, Kaiser, and Gómez (2013) found that research on the adoption of farm to hospital programs was "extremely limited" and "nearly nonexistent" (p. 38). Further, they noted that independent factors that might influence a hospital's decision to adopt local food programs have not been explored. This study has taken one step toward addressing these gaps in the research literature.

An underlying purpose of this study was to encourage additional research on related topics and with the hope that it would initiate conversations that will build knowledge, expand the literature, and put into practice effective programming to promote and expand the use of local foods in the hospital and health-care industry across Ohio and nationwide. Farm-to-hospital initiatives can positively affect our nation's health and local economies. They can enhance a hospital's public relations. In addition, they can provide opportunities for food system workers to create new partnerships benefiting hospitals, health-care institutions, local farmers, and food production and distribution operations, coalescing in triple-bottom-line results that deliver positive social, environmental, and economic outcomes.

\section{References}

American Medical Association [AMA]. (2012, February 28). AMA releases online physician resource to help patients make healthy food choices [Press release]. Retrieved from http://www.ama-assn.org/ama/ $\mathrm{pub} /$ news/news/2012-02-28-healthy-food-choicesmodule.page

Beery, M., \& Vallianatos, M. (2004). Farm to hospital: Promoting health and supporting local agriculture

[Research brief]. Center for Food and Justice, Urban and Environmental Policy Institute, Occidental College. Retrieved from the Strategic Alliance for Healthy Food and Activity Environments website: http://www.eatbettermove more.org/SA/enact/healthcare/documents/health care.farmtoinst.farm_to_hospital.pdf

Bellows, B. C., Dufour, R., Bachmann, J., Green, C., \& Moore, N. (2013). Bringing local food to local institutions: A resource guide for farm to institution programs (Report no. IP242). National Center for Appropriate Technology. Retrieved from https://attra.ncat.org/ attra-pub/summaries/summary.php?pub=261

Benson, M. C. (2013). Exploring food system change through a mixed methods analysis of Cooperative Extension's role in the farm to school movement (Doctoral dissertation). Virginia Polytechnic Institute and State University, Blacksburg, Virginia. Retrieved from http://hdl.handle.net/10919/22077

Buck, M. (2012). A guide to developing a sustainable food purchasing policy. Portland, Oregon: Association for the Advancement of Sustainability in Higher Education, Food Alliance, Health Care Without Harm, Institute for Agricultural Trade and Policy, and Oregon Center for Environmental Health. Retrieved from http://www.sustainablefoodpolicy. org/SustainableFoodPolicyGuide.pdf

Center for Health and the Global Environment. (2012, February). Why should hospitals adopt a bealthy and sustainable food policy? [Online video]. Harvard T. H. Chan School of Public Health. Retrieved from http://chge.med.harvard.edu/resource/healthyand-sustainable-food-hospitals

Centers for Disease Control and Prevention [CDC]. (1996, June 14). Guidelines for school health programs to promote lifelong healthy eating. Morbidity and Mortality Weekly Report, 45(RR-9), 1-33. http://www.cdc.gov/mmwr/preview/mmwrhtml/ $\underline{00042446 . h t m}$ 
CDC. (2013). Farmers markets, community supported agriculture, and local food distribution. Retrieved from http://www.cdc.gov/healthyplaces/healthtopics/ healthyfood/markets.htm

Clancy, K. (2013). High-priority research approaches for transforming U.S. food systems. Journal of Agriculture, Food Systems, and Community Development, 3(4), 5-7. http://dx.doi.org/10.5304/jafscd.2013.034.021

Cleveland Clinic. (2013, May 30). Cleveland Clinic continues to support community access to locally grown food: Community farmers market opens June 5 for sixth season [Press release]. Retrieved from http://my.clevelandclinic.org/media_relations/ library/2013/2013-05-30-cleveland-cliniccontinues-to-support-community-access-to-locallygrown-food.aspx

Cohen, L. (2013, February 17). Let food be your medicine: Diet and cancer prevention [Blog post]. Retrieved from http://www.huffingtonpost.com/lorenzo-cohenphd/diet-cancer-prevention b 2665176.html

Cram, P., Nallamothu, B. K., Fendrick, A. M., \& Saint, S. (2002). Fast food franchises in hospitals [Letter]. Journal of the American Medical Association, 287(22), 2945-2946.

http://dx.doi.org/10.1001/jama.287.22.2942

Cromp, D., Cheadle, A., Solomon, L., Maring, P., Wong, E., \& Reed, K. M. (2012). Kaiser Permanente's farmers' market program: Description, impact, and lessons learned. Journal of Agriculture, Food Systems, and Community Development, 2(2), 29-36. http://dx.doi.org/10.5304/jafscd.2012.022.010

Denton, C. (n.d.). How does food impact health? Retrieved October 11, 2013 from the University of Minnesota, Taking Charge of Your Health \& Wellbeing website: http://www.takingcharge. csh.umn.edu/explore-healing-practices/foodmedicine/how-does-food-impact-health

Dunning, R., Creamer, N., Massey Lelekacs, J., O’Sullivan, J., Thraves, T., \& Wymore, T. (2012). Educator and institutional entrepreneur: Cooperative Extension and the building of localized food systems. Journal of Agriculture, Food Systems, and Community Development, 3(1), 99-112. http://dx.doi.org/10.5304/jafscd.2012.031.010

eXtension. (2013). Food systems introduction. Retrieved from http://www.extension.org/pages/18378/ food-systems-introduction
Feenstra, G. W. (1997). Local food systems and sustainable communities. American Journal of Alternative Agriculture, 12(1), 28-36. http://dx.doi.org/10.1017/S0889189300007165

Feenstra, G. (2002). Creating space for sustainable food systems: Lessons from the field. Agriculture and Human Values, 19(2), 99-106. http://dx.doi.org/10.1023/A:1016095421310

Feenstra, G., McGrew, S., \& Campbell, D. (1999). Entrepreneurial community gardens: Growing food, skills, jobs and communities (Publication No. 21587). University of California, Division of Agriculture and Natural Resources Publications. Retrieved from http://anrcatalog.ucdavis.edu/Details.aspx?itemNo $=21587$

Frith, K. (2007). "Is local more nutritious?” It depends. Cambridge, Massachusetts: Harvard School of Public Health. Retrieved from http://chge.med.harvard.edu/sites/default/files/ resources/local nutrition.pdf

Gaby, S. G. (2011). Supporting healthy food choices for workers at Aberdeen Hospital. Ottawa: Library and Archives Canada $=$ Bibliothèque et Archives Canada

George, V. (2011). Scaling up and preserving local food values: A value chain analysis of local food procurement in a metropolitan public school system (Master's thesis). Michigan State University, East Lansing, Michigan. Retrieved from ProQuest Dissertations and Theses (Accession No. 109).

Gordon, E. (2012, April 9). Fast food chains in cafeterias put hospitals in a bind [Blog post]. Retrieved from National Public Radio's The Salt blog: http://www.npr.org/blogs/thesalt/2012/04/05/ $150091951 /$ fast-food-chains-in-cafeterias-puthospitals-in-a-bind

Gustafson, K. (2012, May 20). What colleges can bring to the table [Commentary]. Chronicle of Higher Education. Retrieved from http://chronicle.com/ article/What-Colleges-Can-Bring-to-the/131923/

Halweil, B. (2007). Still no free lunch: Nutrient levels in U.S. food supply eroded by pursuit of high yields. Washington, D.C.: The Organic Center. Retrieved from https://www.organic-center.org/publications/stillno-free-lunch-nutrient-levels-in-u-s-food-supplyeroded-by-pursuit-of-high-yields /

Health Care Without Harm [HCWH]. (2006). Food and food purchasing: A role for health care. Arlington, Virginia: Author. Retrieved from http://www.noharm.org/lib/downloads/food/ Food and Food Purchasing.pdf 
HCWH. (2013). About us. Retrieved from http://www.noharm.org/all regions/about/

Institute of Food Technologists [IFT]. (2012). Hospital foodservice initiatives: Exciting food innovation implications. Retrieved from http://www.ift.org/knowledgecenter/focus-areas/food-health-and-nutrition/ hospital-foodservice-initiatives.aspx

Inwood, S. M., \& Sharp, J. S. (2012). Farm persistence and adaptation at the rural-urban interface: Succession and farm adjustment. Journal of Rural Studies, 28(1), 107-117. http://dx.doi.org/10.1016/j.jrurstud.2011.07.005

Iowa State University. (n.d.). Beginning Farming Center. Iowa State University Extension and Outreach. Retrieved from http://www.extension.iastate. $\underline{\mathrm{edu} / \mathrm{bfc} /}$

Johnson, R., Aussenberg, R. A., \& Cowan, T. (2013). The role of local food systems in U.S. farm policy [Report No. R42155]. Washington, D.C.: Congressional Research Service. Retrieved from http://www.fas.org/sgp/crs/misc/R42155.pdf

Kaiser Permanente. (2013). Promoting sustainable farming and food choices. Oakland, California: Author.

Katzman, R., \& Graham, C. (2011). Institutionalizing a farm-to-college system. Kenyon College. Retrieved from http:// farmtocollege.wordpress.com/

Klein, K. (2012, October 12). A new prescription for the local food movement. The Nation. Retrieved from http://www.thenation.com/article/170526/newprescription-local-food-movement

Knepper, G. W. (2003). Obio and its people (Bicentennial Edition). Kent State University Press.

Lawrence, S., Boyle, M., Craypo, L., \& Samuels, S. (2009). The food and beverage vending environment in health care facilities participating in the Healthy Eating, Active Communities program. Pediatrics, 123(Supp. 5), S287S-S292. http://dx.doi.org/10.1542/peds.2008-2780G

Lee, J. (2013, April 27). Changes on the menu. Retrieved from http://www.modernhealthcare.com/ article/20130427/MAGAZINE/301049827

Lesser, L. I. (2006). Prevalence and type of brand name fast food at academic-affiliated hospitals [Research letter]. Journal of the American Board of Family Medicine, 19(5), 526-527. http://dx.doi.org/10.3122/jabfm.19.5.526

Lesser, L. I., Hunnes, D. E., Reyes, P., Arab, L., Ryan, G. W., Brook, R. H., \& Cohen, D. A. (2012).
Assessment of food offerings and marketing strategies in the food-service venues at California children's hospitals. Academic Pediatrics, 12(1), 62-67. http://dx.doi.org/10.1016/j.acap.2011.09.004

Lev, L., \& Stevenson, G. W. (2013). Values-based food supply chains: An introduction to nine case studies. Madison, Wisconsin: Center for Integrated Agricultural Systems, University of WisconsinMadison. Retrieved from http://www.cias.wisc. edu/wp-content/uploads/2013/04/introsection final072513.pdf

Low, S. A., \& Vogel, S. (2011). Direct and intermediated marketing of local foods in the United States (Economic Research Report No. ERR-128). Washington, D.C.: U.S. Department of Agriculture Economic Research Service. Retrieved from http://www.ers.usda.gov/publications/erreconomic-research-report/err128.aspx

Martinez, S., Hand, M. S., Da Pra, M., Pollack, S., Ralston, K., Smith, T., Vogel, S., Clark, S., Lohr, L., Low, S. A., \& Newman, C. (2010). Local food systems: Concepts, impacts, and issues (Economic Research Report No. ERR-97). Washington, D.C.: USDA, Economic Research Service. Retrieved from http://www.ers.usda.gov/publications/erreconomic-research-report/err97.aspx

Matheson, A. (2012). From farm to hospital cafeteria table [Press release]. Cambridge, Massachusetts: Center for Health and the Global Environment, Harvard Medical School. Retrieved from http://chge.med.harvard.edu/sites/default/files/ Frith PR HealthyFoodConference.pdf

Matson, J., \& Thayer, J. (2013). The role of food hubs in food supply chains. Journal of Agriculture, Food Systems, and Community Development, 3(4), 43-47. http://dx.doi.org/10.5304/jafscd.2013.034.004

MacVean, M. (2009, May 20). Kaiser Permanente farmers markets put nutrition within reach. Los Angeles Times. Retrieved from http://www.latimes.com/features/food/la-fokaiser20-2009may20,0,3231979.story

Mitchell, L. (2009). Federal-State Marketing Improvement Program grant: USD A Agricultural Marketing Service final report: Local foods to local hospitals. Washington, D.C.: USDA, Agricultural Marketing Service. Retrieved from http://www.ams.usda.gov/AMS v1.0/getfile?dDocName=STELPRDC5083205 
National Farm to School Network. (n.d.). The benefits of farm to school. Retrieved May 26, 2015, from http://www.farmtoschool.org/Resources/Benefits FactSheet.pdf

National Sustainable Agriculture Coalition. (2013). Local Farms, Food, and Jobs Act. Retrieved from http://sustainableagriculture.net/our-work/localfood-bill/

O’Hara, J. K., \& Pirog, R. (2013). Economic impacts of local food systems: Future research priorities. Journal of Agriculture, Food Systems, and Community Development, 3(4), 35-42. http://dx.doi.org/10.5304/jafscd.2013.034.003

Ohio Department of Health [ODH]. (n.d.). Directory of registered hospitals. Retrieved on May 26,2015, from http://publicapps.odh.ohio.gov/eid/reports/ Report Output RS.aspx

Ohio Hospital Association [OHA]. (2014). Facts and Figures. Retrieved from http://ohiohospitals.org/ Ohio-Hospitals/facts-and-figures.aspx

Physicians Committee for Responsible Medicine. (2011). The five worst hospital food environments. Retrieved from http://www.pcrm.org/health/reports/the-fiveworst-hospital-food-environments

Ritchie, S. M., \& Chen, W.-T. (2011). Farm to school: A selected and annotated bibliography (Special Reference Briefs Series No. SRB 2011-02). Beltsville, Maryland: USDA, Agricultural Research Service, National Agricultural Library. Retrieved from http://www.nal.usda.gov/afsic/pubs/srb1102. $\underline{\text { shtml }}$

Rogers, E. M. (1962). Diffusion of innovations. New York: Free Press.

Rogers, E. M. (1995). Diffusion of innovations (5th Ed.). New York: Free Press.

Sachs, E. Q. (2011). Healthy food in health care sustainable food systems initiatives in Bay Area hospitals. Davis, California: University of California, Davis. http://proquest.umi.com/pqdweb?did $=252935755$ $1 \&$ sid $=11 \&$ Fmt $=2 \&$ clientId $=48051 \&$ RQT $=309 \&$ $\underline{\mathrm{VName}}=\mathrm{PQD}$

Saha, N. S., \& Nath, N. (2006). Minimally processed fruits and vegetables: Freshness with convenience. Journal of Food Science and Technology, 43(6), 561-570.

Sanger, K., \& Zenz, L. (2004). Farm-to-cafeteria connections: Marketing opportunities for small farms in Washington state. Washington State Department of Agriculture Small Farm and Direct Marketing Program.
Retrieved from http://agr.wa.gov/Marketing/Small Farm/docs/102-Farm'ToCafeteriaConnectionsWeb.pdf

Sharp, J. S., Clark, J. K., Davis, G. A., Smith, M. B., \& McCutcheon, J. S. (2011). Adapting community and economic development tools to the study of local foods: The case of Knox County, Ohio. The Journal of Extension, 49(2), Article 2FEA4. http://www.joe.org/joe/2011april/a4.php

Smith, B. J., II, Kaiser, H. M., \& Gómez, M. I. (2013). Identifying factors influencing a hospital's decision to adopt a farm-to-hospital program. Agricultural and Resource Economics Review, 42(3), 508-517. http://purl.umn.edu/161387

Smith, T. (2012, June 24). Columbus, Ohio: Test market of the U.S.A. CBS News. Retrieved from http://www.cbsnews.com/8301-3445 16257404087/columbus-ohio-test-market-of-the-u.s.a/

Stevenson, G. W., \& Pirog, R. (n.d.). Values-based food supply chains: Strategies for agri-food enterprises-of-themiddle. Washington, D.C.: USDA Agricultural Marketing Services. Retrieved from http://www.ams.usda.gov/AMSv1.0/getfile?dDoc Name $=$ STELPRDC5091497

Sylvester, R. (2011). USD A: Number of farmers markets up $31 \%$ in Obio over last year. Retrieved from Ohio Farmers Union website: http://ohfarmersunion. org/2011/08/usda-number-of-farmers-markets-up31-in-ohio-over-last-year/

Ugalde, M. (2012). Results from an assessment survey for school food service directors and school foodservice managers participating in the 2011-2012 South Carolina farm to school program (Master's thesis). Retrieved from ProQuest Dissertations and Theses (Accession No. 1518327).

U.S. Department of Agriculture [USDA]. (2012). National farmers markets directory search. Retrieved from http:// farmersmarkets.usda.gov/

USDA. (2013). Know Your Farmer, Know Your Food: Farm to institution initiatives. Retrieved from http://www.usda.gov/wps/portal/usda/usdahome ?contentidonly $=$ true $\&$ contentid $=\mathrm{KYF}$ Compass

Farm to Institution.html

Virginia Tech Department of Agricultural and Extension Education. (2012). Results of the 2011 Virginia farm to school program survey of school nutrition directors. Blacksburg, Virginia: Author. 
Wiseman, A., Boothe, A., Reynolds, R., \& Belay, B. (2011). Healthy hospital choices: Recommendations and approaches from an expert panel. Atlanta, Georgia: Centers for Disease Control and Prevention, National Center for Chronic Disease Prevention and Health Promotion. Retrieved from http://www.cdc.gov/nccdphp/dnpao/hwi/docs/ HealthyHospBkWeb.pdf
Worley, S. \& Strobbe, M. (2012). Scaling-up: Perspectives from growers and buyers on barriers and benefits to wholesale marketing of local fruits and vegetables. Ames, Iowa: Leopold Center for Sustainable Agriculture at Iowa State University. Retrieved from https://www.leopold.iastate.edu/sites/default/files /pubs-and-papers/2012-10-scaling-perspectivesgrowers-and-buyers-barriers-and-benefitswholesale-marketing-local-fruits-and-v.pdf 